DOI: https://doi.org/10.31933/dijms.v2i6 Received: $23^{\text {th }}$ June 2021 , Revised: $25^{\text {th }}$ July 2021 , Publish: $15^{\text {th }}$ August 2021

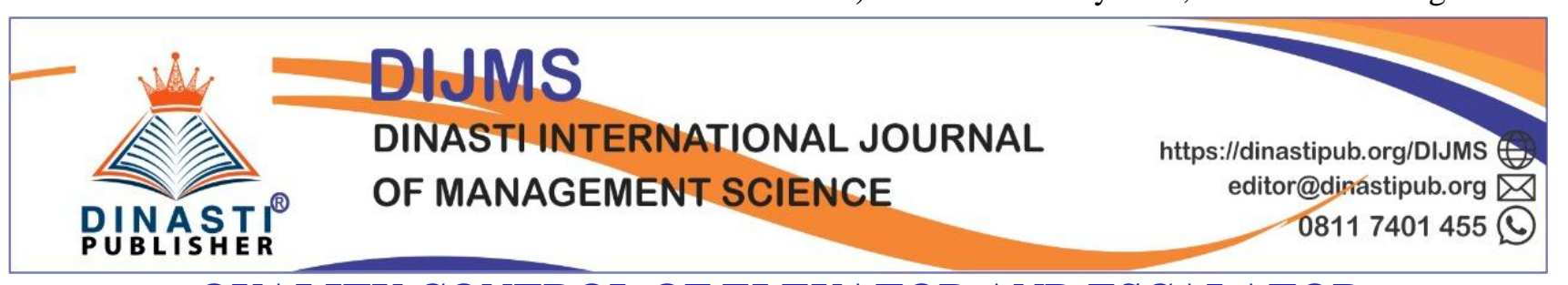

\title{
QUALITY CONTROL OF ELEVATOR AND ESCALATOR MAINTENANCE SERVICES AT PT ABC SURABAYA
}

\author{
Aulia Harris ${ }^{1}$., Sugiyono Madelan ${ }^{2}$, Ahmad Badawi Saluy ${ }^{3}$. \\ 1) Universitas Mercu Buana, Jakarta, Indonesia, harris.anggi@ gmail.com \\ 2) Universitas Mercu Buana, Jakarta, Indonesia, sugiyono@mercubuana.ac.id \\ 3) Universitas Mercu Buana, Jakarta, Indonesia, ahmad.badawi@mercubuana.ac.id
}

\section{Corresponding Author: Aulia Harris ${ }^{1}$}

Abstract: This study aims to analyze the relationship between service quality, product quality and trust in the decision to use brand image as an intervening medium inservice providers elevator and escalator. This type of research is an explanatory research type using quantitative descriptive research methods. The sample used was 70 respondents. The data was processed using themethod Structural Equation Model-Partial Least Square. The results showed that: (1) service quality and product quality had a positive and significant effect on brand image; (2) service quality, brand image and trust have a positive and significant effect on usage decisions; (3) there is a positive and significant influence between service quality and product quality on the decision to use brand image as a mediating variable.

Keywords: Service Quality, Product Quality, Trust, Brand Image, Usage Decision

\section{INTRODUCTION}

In planning to build infrastructure, high-rise buildings and high-rise housing are now synonymous with the presence of an elevator or escalator which is used as a vertical transportation tool to move people or goods from one level to another. The use of technology that follows the development of modern times has become an elevator reliability to further facilitate human work effectively and efficiently. This is based on Law Number 28 of 2002 Article 29, it has been stated that the ease of building vertical connections, including vertical transportation facilities, can be in the form of providing stairs, ramps, and lifts.

To meet the needs of high-rise buildings or other facilities for the use of this vertical mode of transportation, it is inseparable from the initial step in selecting a reputable company engaged in the procurement, installation and maintenance of elevators, escalators, travolators and moving walks. Includes schedule procurement and installationin accordance with the time plan for the construction of the building.

This activity will increase competitiveness in the procurement of new lift units. Procurement and new installation are customer expectations of the design, specifications and materials that are mutually agreed upon during the buying and selling process. Currently, there are more than 50 national and multi-national companies engaged in elevators and escalators as 
sole distributors and maintenance services.

Table 1. The results of PT ABC achievement on the service quality dimension Source: data from the company PT ABC

\begin{tabular}{|c|c|c|c|}
\hline \multicolumn{2}{|c|}{ Dimensions of the } & \multirow{2}{*}{$\begin{array}{c}\text { Achievement } \\
\\
0.753\end{array}$} & \multirow{2}{*}{$\begin{array}{c}\text { Company's Standard } \\
0.80\end{array}$} \\
\hline Product Quality & $\begin{array}{l}\text { Features of saving energy } \\
\text { and minimum space can be } \\
\text { an attraction for consumers }\end{array}$ & & \\
\hline \multirow{2}{*}{\multicolumn{4}{|c|}{$\begin{array}{l}\text { Table } 1 \text { shows that the results of the achievement of PT ABC based o } \\
\text { assessments on the dimensions of service quality on the use tools of modern, safety a } \\
\text { technology are still below the standards set by the company with a difference of } 0.02 \\
\text { Table } 2 \text {. The results of PT ABC achievement on the product quality dimension } \\
\text { Source: PT ABC company data }\end{array}$}} \\
\hline & & & \\
\hline \multicolumn{2}{|c|}{ Dimensions of the } & Achievement & Company's Standard \\
\hline Brand Image & $\begin{array}{l}\text { Considering the product } \\
\text { because of safety and the } \\
\text { latest technology }\end{array}$ & 0.894 & 0.93 \\
\hline
\end{tabular}

Table 2 shows that the results of the achievement of PT ABC based on consumer assessments on the dimensions of product quality on the energy saving and minimum space features can be an attraction for current consumers, which are still below the standard set by the company with a difference of 0.047 .

Table 3. PT ABC achievement results on the brand image dimension

Source: PT ABC company data

\begin{tabular}{ccc}
\hline Dimensions of the & Achievement & Company's Standard \\
\hline Trust & $\begin{array}{l}\text { Recommend manufacturers } \\
\text { to other people / companies } \\
\text { / agencies. }\end{array}$ \\
\hline
\end{tabular}

Table 3 shows that the results of the achievement of PT ABC are based on consumer assessments of the brand image dimension in considering the product because safety and the latest technology are still below the standards set by the company with a difference of 0.036 . 
Table 4. The results of PT $\mathrm{ABC}$ achievement on the dimension of trust. Source: PT ABC company data

Table 4 shows that the results of the achievement of PT ABC based on consumer ratings

\begin{tabular}{|c|c|c|c|}
\hline \multicolumn{2}{|c|}{ Dimensions of the } & \multirow{2}{*}{$\begin{array}{c}\text { Achievement } \\
0.866\end{array}$} & \multirow{2}{*}{$\begin{array}{c}\text { Company's Standard } \\
0.90\end{array}$} \\
\hline Decision to Use & $\begin{array}{l}\text { Will reuse products from } \\
\text { the same manufacturer }\end{array}$ & & \\
\hline \multicolumn{4}{|c|}{$\begin{array}{l}\text { on the dimension of trust in recommending producers to other people / companies / agencies } \\
\text { still below the standard set by the company with a difference of } 0.012 \text {. }\end{array}$} \\
\hline \multicolumn{2}{|c|}{ Period } & Maintenance & Call Back Rate \\
\hline \multicolumn{2}{|c|}{ September 2020 - April 2021} & $\%$ (Fluctuative) & $5 \%-7 \%$ \\
\hline
\end{tabular}

Table 5 The results of PT ABC's achievement on the dimensions of the decision to use Source: PT ABC company data

Table 5 shows that the results of the achievement of PT ABC based on consumer assessments on the dimensions of the decision to use the Will to reuse products from the same manufacturer are still below the standard set by the company with a difference of 0.034 .

Table 6. Percentage of Number of Maintenance Units PT ABC Year 2020 - 2021 Source: PT ABC company data

\begin{tabular}{ccc}
\hline Dimensions of the & Achievement & Company's Standard \\
\hline Service Quality & $\begin{array}{l}\text { Use tools } \text { of modern, safety } \\
\text { and the latest technology }\end{array}$ & 0,793
\end{tabular}

Based on table 6 that the percentage of maintenance conducted by PT ABC for the period of September 2020 - April 2021, it fluctuated with a magnitude of $80 \%$ - 100\%, meaning that the number of maintenance and maintenance units for elevators and escalators was not constant every month. While the call-back rate reaches $5 \%-7 \%$ with the standard used is $2 \%$. This shows that the company still has problems with service quality, product, trust, brand image on consumer decisions in using maintenance service companies elevator and escalator.

Based on these problems, the researchers felt the need to conduct a study to analyze the factors that influence consumers in choosing elevator and escalator maintenance service providers in service providers with the absence of customer assessment results that do not meet standards companywith the title "Quality Control of Elevator Maintenance Services. and Escalator at PT ABC in Surabaya.

\section{Problem Identification}


Based on the description of the discussion in the background, there are several problems faced, namely:

1. The results of achieving the maintenance routine are company'sstill fluctuating.

2. There are still customer complaints about product quality (call back rate report) which is volatile.

3. There is still a difference from the results of the achievement of PT ABC to consumer ratings in terms of service quality.

4. There is still a difference from the results of the achievement of PT ABC to consumer ratings in terms of product quality.

5. There is still a difference from the results of the achievement of PT ABC to consumer ratings in terms of brand image.

6. There is still a difference from the results of the achievement of PT ABC to consumer ratings in terms of trust.

7. There is still a difference from the results of the achievement of PT ABC to consumer ratings in terms of usage decisions.

\section{LITERATURE REVIEW}

\section{Operational Management}

Nigel Slack, et al (2013) explains that Operations Management is a form of company activity in managing its resources in making and providing services from the products produced. Heizer and Render (2005) explain that the focus of operations management is divided into three, namely cost focus, quality focus and customization focus.

\section{Total Quality Management}

According to Nigel Slack, et al (2013) defines that Total Quality Management (TQM) is a philosophy carried out by an organization to improve quality by placing quality as the core in the activities of an operation. Total Quality Management is an effective system to improve quality by integrating quality development and quality maintenance so that production and services can meet customer expectations and satisfaction.

\section{Quality Control}

According to Sofyan Assauri (in Hayu Kartika, 2013) control and supervision are activities carried out to ensure that production and operating activities are carried out in accordance with what was planned and if deviations occur, these deviations can be corrected so that what is expected can be achieved.

\section{Service Quality}

Parasuraman et.al (2013:44): "Service quality is the customer perception's of the superiority of the service". It means that service quality is perception customers to the benefits of a service. Kotler and Armstrong $(2014 ; 681)$ stated "Quality is the totally and characteristics of the product and service that bears on its ability to satisfy stated or implied needs". features and characteristics of the product or service that support its ability to satisfy needs directly or indirectly live.

\section{Product Quality}


According to Kotler and Armstrong (2014: 259), a product is anything that can be offered to the market to attract attention, acquisition, use, or consumption that might satisfy customers.

\section{Brand Image}

According to Kotler and Armstrong (2012) brand image is a set of consumer beliefs about a particular brand. Kotler and Armstrong (2014; 681) stated "Quality is the totally and characteristics of the product and service that bears on its ability to satisfy stated or implied needs". features and characteristics of the product or service that support its ability to satisfy needs directly or indirectly live.

\section{Trust}

Trust is all knowledge possessed by consumers and all conclusions that consumers make about objects, attributes and benefits (Mowen and Minor, 2002).

\section{Usage Decision}

According to Peter and Olson Christiana (2008) decision making is an integration process that involves knowledge to evaluate two or more alternatives and choose one of them. The decision in a general sense is "a decision is the selection of an option from two or more alternative choices" which is a person's decision where he chooses one of several available alternative choices.

\section{After sales}

According to Kotler, Keller (2011: 237) "A company must determine how to offer aftersales services (eg, maintenance and repair and training services to customers)". Companies provide after-sales service usually as a form of responsibility given to the goods they have sold.

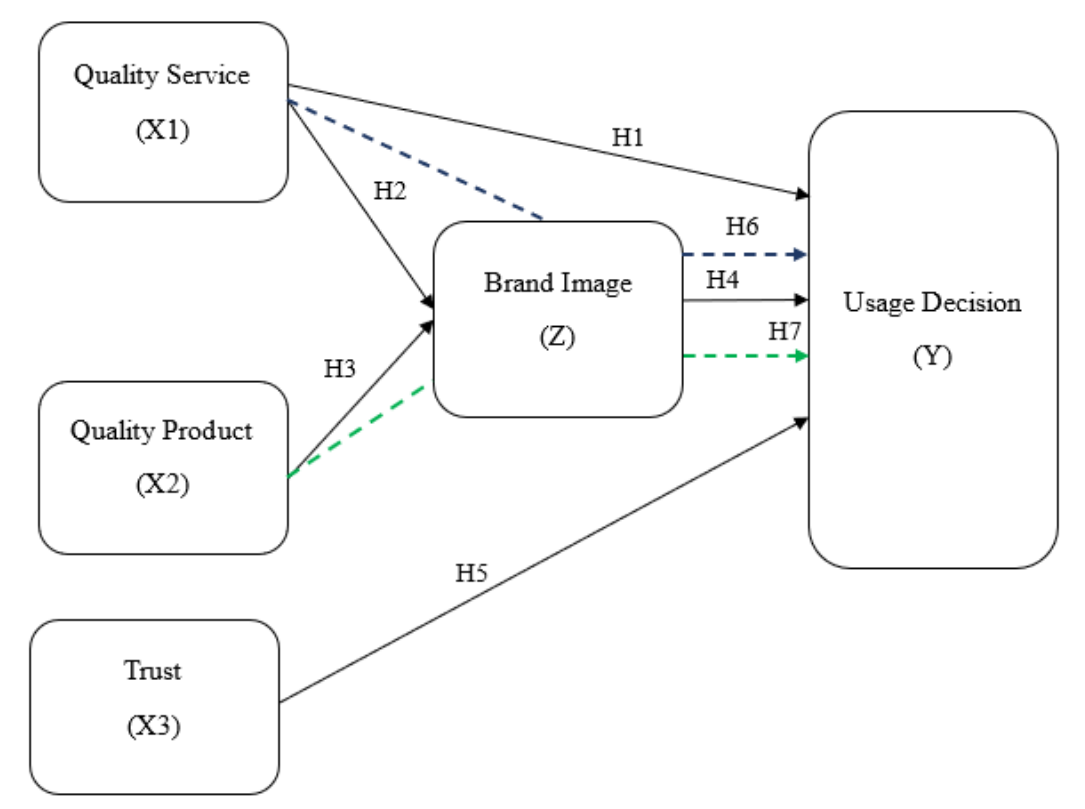

Source: PT ABC company data

Figure 1. Framework Used

\section{RESEARCH METHOD}

Research Design The 
type of approach that the researcher uses is a quantitative descriptive analysis approach with explanatory research. According to (Sani \& Vivin, 2013; 180) explanatory research is to test hypotheses between hypothesized variables.

\section{Variable Operational}

Table 7. Variable Operational

\begin{tabular}{|c|c|}
\hline Variable & Dimensions Variable \\
\hline Service Quality & 1. Tangibles \\
\hline \multirow[t]{4}{*}{ (Independent Variables - X1) } & 2. Reliability \\
\hline & 3. Responsivity \\
\hline & 4. Assurance \\
\hline & 5. Empathy \\
\hline Product Quality & 1. Performances \\
\hline \multirow[t]{5}{*}{ (Independent Variable - X2) } & 2. Features \\
\hline & 3. Conformance to \\
\hline & Specification \\
\hline & 4. Durability \\
\hline & 5. Aesthetics \\
\hline Trust & 1. Satisfaction Guarantee \\
\hline \multirow[t]{2}{*}{ (Mediation Variable - X3) } & 2. Caution \\
\hline & 3. Directness \\
\hline Brand Image & 1. Recognition \\
\hline \multirow[t]{2}{*}{ (Independent Variable - Z) } & 2. Reputation \\
\hline & 3. Affinity \\
\hline \multirow{4}{*}{$\begin{array}{c}\text { Usage Decision } \\
\text { (Dependent Variable - Y) }\end{array}$} & $\begin{array}{l}\text { 1. Selection } \\
\text { Products }\end{array}$ \\
\hline & $\begin{array}{ll}\text { Products } \\
\text { 2. } & \text { Term }\end{array}$ \\
\hline & $\begin{array}{ll}\text { 2. } & \text { Term } \\
\text { 3. } & \text { Job volume }\end{array}$ \\
\hline & 3. Job volume \\
\hline
\end{tabular}

Source: Primary data processed (2020)

\section{Population and Sample}

The population used is consumers who have an elevator and or escalator in the building as many as 85 consumers.

The sample used is based on the Slovin formula, as many as 70 respondents with the following criteria:

1. Consumers who own and use elevators and or escalators, both in buildings and housing with various brands in Jakarta.

2. Consumers who own elevators and or escalators with brands that have been or are still customers of PT ABC

\section{Data Sources}

Using a questionnaire with google forms, interviews, library studies and company documentation.

\section{Analysis Method}

Using SEM (Structural Equation Model) using software SmartPLS Ver 3.3.3 . 


\section{FINDINGS AND DISCUSSION}

\section{Outer Model}

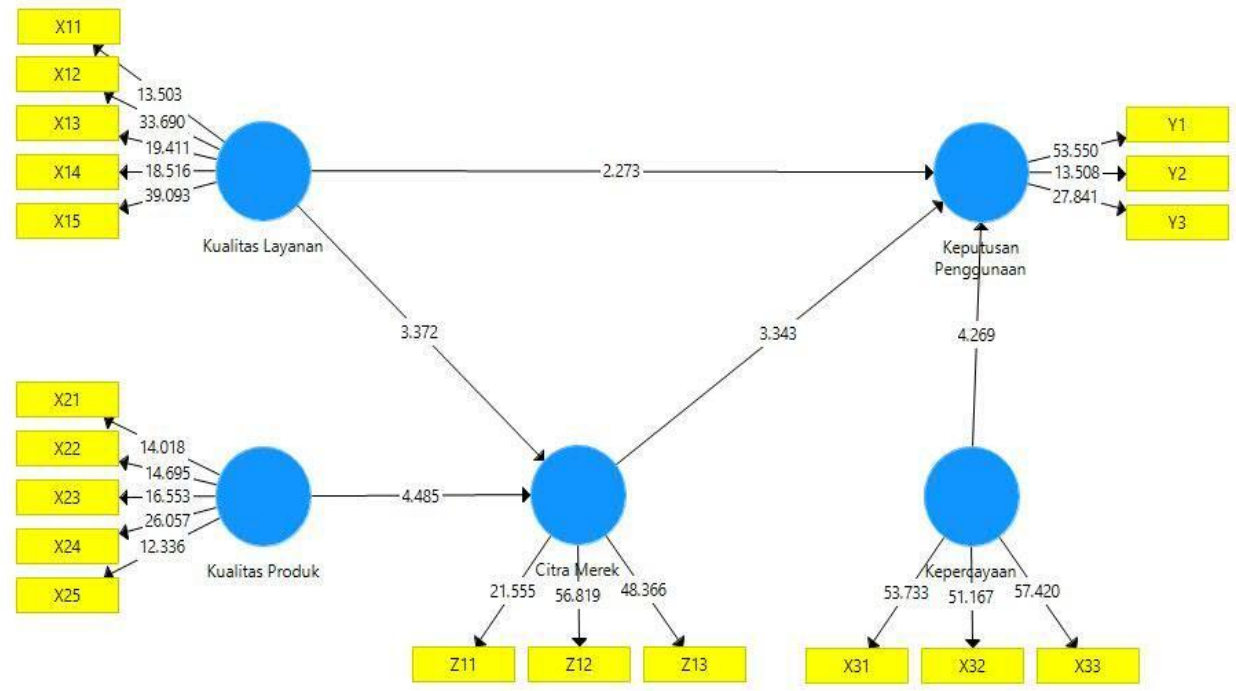

Source: SmartPLS Data Processing Results

Figure 2. Outer Model Measurement

\section{Validity test}

According to Jogiyanto (2007), validity in research is explained as a degree of accuracy of research measuring instruments about the true meaning being measured.

\section{Convergent Validity}

To test convergent validity, the outer loading value or loading factor is used.

Table 8. Outer Loadings (Measurement Model)

\begin{tabular}{lllcl}
\hline Construct & Items & Outer Loading & Terms & Results \\
\hline X11 & 0,797 & Valid \\
X12 & 0,878 & Valid \\
Service Quality & X13 & 0,837 & Valid \\
& X14 & 0,793 & Valid \\
& X15 & 0,899 & Valid \\
X21 & 0,810 & Valid \\
X22 & 0,753 & Valid \\
Product Quakity & X23 & 0,852 & Valid \\
& X24 & 0,867 & Valid \\
& X25 & 0,780 & Valid \\
\hline
\end{tabular}




\begin{tabular}{lccc}
\hline & X31 & 0,918 & Valid \\
Trust & X32 & 0,931 & Valid \\
& X33 & 0,926 & Valid \\
Z11 & 0,941 & Valid \\
Brand Image & Z12 & 0,866 & Valid \\
& Z13 & 0,912 & Valid \\
& Y1 & 0,894 & Valid \\
Usage Decision & Y2 & 0,943 & Valid \\
& Y3 & 0,916 & Valid \\
\hline
\end{tabular}

Source: Analysis Results using SmartPLS 3.3.3

Table 8 shows that the entire loading factor value of each indicator in the variables and dimensions is above 0.7 .

\section{Discriminant Validity}

This test is based on the value of the cross loading measurement with the construct and the value of Average Variance Extracted (AVE).

Table 9. Fornell Larcker Critical Variable Research

\begin{tabular}{llllll}
\hline & $(\mathrm{Z})$ & $(\mathrm{X} 3)$ & $(\mathrm{Y} 1)$ & $(\mathrm{X} 1)$ & $(\mathrm{X} 2)$ \\
\hline$(\mathrm{Z})$ & 0,918 & & & & \\
$(\mathrm{X} 3)$ & 0,822 & 0,925 & & & \\
$(\mathrm{Y} 1)$ & 0,808 & 0,821 & 0,907 & & \\
$(\mathrm{X} 1)$ & 0,848 & 0,823 & 0,803 & 0,842 & \\
$(\mathrm{X} 2)$ & 0,866 & 0,798 & 0,801 & 0,848 & 0,814 \\
\hline
\end{tabular}

Source: The results of the analysis using SmartPLS 3.3.3

Based on table 9 above, it shows that each indicator in the research variable has the value cross loading largest on the variables it forms compared to the value cross loading on other variables.

Table 10. Nilai AVE (Average Variance Extracted) Research Model

\begin{tabular}{cc}
\hline Variabel & Nilai AVE \\
\hline Quality Service & 0,709 \\
Quality Product & 0,662 \\
Brand Image & 0,843 \\
Trust & 0,856 \\
Decision Usage & 0,822 \\
\hline
\end{tabular}

Source: Analysis Results using SmartPLS 3.3.3

Based on table 10 above, it shows that the AVE value for all research variables and research dimensions is above 0.5 , which means that the AVE value for testing discriminant validity has met the requirements for further testing. 


\section{Reliability Test}

Test The reliability test is used to measure the consistency of the respondents' consistency in answering the question items in the questionnaire.

\section{Composite Reliability}

To test the value of the reliability of indicators on a variable.

Table 11. Composite Reliability

\begin{tabular}{cccl}
\hline Variable & $\begin{array}{c}\text { Composite } \\
\text { Reliability }\end{array}$ & Standard & Results \\
\hline Quality Service & 0,924 & & Reliable \\
Quality Product & 0,907 & & Reliable \\
Brand Image & 0,941 & $>0,700$ & Reliable \\
Trust & 0,947 & & Reliable \\
Decision Usage & 0,933 & & Reliable \\
\hline
\end{tabular}

Source: Analysis Results using SmartPLS 3.3.3

Based on the data in table 11, it shows that thevalue composite reliability for all research variables is $>0.7$. So that the value of each variable has met composite reliability

\section{Cronbach Alpha}

Aims to strengthen the reliability test results.

Table 12.

Alpha

\begin{tabular}{cccl}
\hline Variabel & $\begin{array}{c}\text { Cronbach } \\
\text { Alpha }\end{array}$ & Standard & Keterangan \\
\hline Quality Service & 0,897 & & Reliable \\
Quality Product & 0,871 & & Reliable \\
Brand Image & 0,906 & $>0,700$ & Reliable \\
Trust & 0,916 & & Reliable \\
Decision Usage & 0,892 & & Reliable \\
\hline
\end{tabular}

Cronbach

Source: Analysis Results using SmartPLS 3.3.3

Based on the data in table 12, it shows that the value Cronbach Alpha for all research variables is $>0.7$ (Ghozali and Latan, 2015). So that the value of each variable has met the value Cronbach Alpha and it can be concluded that all variables have a high level of internal consistency reliability.

\section{Inner Model}

Coefficient of Determination Test / R Square (R2)

Table 13. Nilai $R$-Square

\begin{tabular}{ccc}
\hline Variable & $R$ Square & $R$ Square Adjusted \\
\hline Brand Image & 0,794 & 0,788 \\
Decision Usage & 0,743 & 0,731 \\
\hline
\end{tabular}

Source: Analysis Results using SmartPLS 3.3.33

Based on table 13, it shows that the value $R$-Square of $79.4 \%$ in the Brand Image variable with a strong category is influenced by the service quality and product quality variables, while the remaining $20.6 \%$ is influenced by other variables outside of the research. 


\section{Goodness of Fit}

Following the calculation of Q2 as follows (Hair et al., 2011).

$$
\begin{aligned}
& Q^{2}=1-\left(1-R_{1} 2\right)\left(1-{R_{2}}^{2}\right) \\
& Q^{2}=1-(1-0,788)(1-0,731) \\
& Q^{2}=1-(0,212 \times 0,269)=1-0,06=0,94
\end{aligned}
$$

\section{Hypothesis Results}

Calculation of this hypothesis test using SmartPLS 3.3.3 can be seen from the Path Coefficient value, namely the t-statistic value of the relationship between variables in the study.

This hypothesis test can also be done by looking at the t-count and p-value.

In the statistical table, the value of $t$ table with a value of $\mathrm{DF}=\mathrm{n}-\mathrm{k}=70-5=65$ is 1.997

with a significance level of 0.05 . So the decision is

If $\mathrm{P}$-Values $>0.05$ or $\mathrm{t}$-count $<\mathrm{t}$-table, Ho is accepted and $\mathrm{Ha}$ is rejected.

If $\mathrm{P}$-Values $<0.05$ or $\mathrm{t}$-count $>\mathrm{t}$-table, Ho is rejected and $\mathrm{Ha}$ is accepted.

Table 14. Path Coefficient Results

\begin{tabular}{lcccc}
\hline \multicolumn{1}{c}{ Hubungan Antar Konstruk } & $\begin{array}{c}\text { Original } \\
\text { Sample }(O)\end{array}$ & $\begin{array}{c}\text { T Statistics } \\
(\text { O/STDEV })\end{array}$ & P Values & $\begin{array}{c}\text { Hasil } \\
\text { Hipotesa }\end{array}$ \\
\hline Brand Image_-> Decision Usage_ & 0,282 & 3,343 & 0,001 & Accepted \\
Trust_-> Decision Usage _- & 0,387 & 4,269 & 0,000 & Accepted \\
& 0,399 & 3,372 & 0,001 & Accepted \\
Quality Service_-> Brand Image_ & 0,246 & 2,273 & 0,023 & Accepted \\
Quality Service_-> Usage Decision _- & 0,527 & 4,485 & 0,000 & Accepted \\
Quality Product_-> Brand Image__ & & &
\end{tabular}

Source: Analysis Results using SmartPLS 3.3.3

\section{Relationship of Service Quality with Brand Image}

According to the results path coefficient with a value of sample 0.399 which shows a positive number with a t-statistic value of 3.372 greater than 1.997 and a p-value of 0.001 less than 0.05. So that it can be said that the service quality variable has a positive and significant effect on the brand image variable. The results of this study are in accordance with previous research that service quality affects brand image (Levyda, 2015).

\section{Relationship between Brand Image and Decision to Use}

In accordance with the results of the path coefficient with avalue of sample 0.282 which shows a positive number with a t-statistic value of 3.343 greater than 1.997 and a $p$-value of 0.001 less than 0.05 . So that it can be said that the brand image variable has a positive and significant effect on the customer decision variable. The results of this study are in accordance with previous research that brand image affects the decision to use gas station fuel service providers (Ferdy, et al, 2015) 


\section{Product Quality Relationship with Brand Image}

In accordance with the results of the path coefficient with avalue of sample 0.527 which shows a positive number with a t-statistic value of 4.485 greater than 1.997 and a p-value of 0.000 less than 0.05. So it can be said that the product quality variable has a positive and significant effect on the brand image variable. The results of this study are in accordance with previous research that product quality has a positive and significant effect on brand image (Darmajaya, 2018).

\section{Relationship of Trust with Decision to Use}

In accordance with the results of the path coefficient with avalue of sample 0.387 which shows a positive number with a t-statistic value of 4.269 greater than 1.997 and a p-value of 0.000 less than 0.05 . So it can be said that the trust variable has a positive and significant effect on the use decision variable. The results of this study are in accordance with previous research that trust has a significant positive effect on decisions to useproducts smartphone (Putri and Sukaatmadja, 2018).

\section{Relationship of Service Quality with Usage Decisions}

In accordance with the results of the path coefficient with avalue of sample 0.2467 which shows a positive number with a t-statistic value of 2.273 greater than 1.997 and a $p$-value of 0.023 less than 0.05 . So that it can be said that the service quality variable has a positive and significant effect on the use decision variable. The results of this study are in accordance with previous research that trust has a significant positive effect on decisions to useproducts smartphone (Putri and Sukaatmadja, 2018).

\section{Relationship of Service Quality on Usage Decisions with Brand Image as a mediating variable}

There is a positive and significant influence between service quality on usage decisions and brand image as a mediating variable. This is in accordance with theresults path coefficient with avalue of sample 0.112 which shows a positive number with a t-statistic value of 2.511 greater than 1.997 and a p-value of 0.012 less than 0.05 . It can be interpreted that brand image can be a mediation between service quality and the decision to use the service provider. The results of this study are in accordance with previous research that brand image mediates between service quality and usage decisions (Sandi and Rama, 2020).

\section{Relationship of Product Quality on Usage Decisions with Brand Image as a mediating variable}

There is a positive and significant influence between service quality on usage decisions and brand image as a mediating variable. This is in accordance with theresults path coefficient with avalue of sample 0.148 which shows a positive number with a t-statistic value of 2.447 greater than 1.997 and a p-value of 0.015 less than 0.05 . It can be interpreted that brand image can mediate between product quality and the decision to use the service provider. The results of this study are in accordance with previous research that brand image mediates between product quality and usage decisions made by (Irwanty, et al , 2017). 


\section{CONCLUSIONS AND RECOMMENDATIONS}

\section{Conclusions}

In this section, conclusions will be presented on the hypotheses and discussion of research results in the previous chapter, so some conclusions can be drawn from this research as follows:

1. This study proves that service quality has a positive and significant effect on the brand image of service providers maintenance of elevators and escalators.

2. This study proves that product quality has a positive and significant effect on the brand image of companies providing elevator and escalator maintenance services.

3. This study proves that trust has a positive and significant effect on decisions to use companies providing elevator and escalator maintenance services.

4. This study proves that brand image has a positive and significant effect on the decision to use elevator and escalator maintenance service providers.

5. This study proves that service quality has a positive and significant effect on the decision to use elevator and escalator maintenance service providers.

6. This study proves that there is a positive and significant influence between service quality on usage decisions and brand image as a mediating variable.

7. This study proves that there is a positive and significant influence between product quality on usage decisions and brand image as a mediating variable.

\section{Suggestions}

That can be given based on the results of this study are as follows:

1. For further research, other variables can be used to test the effect on interest in reusing elevator and escalator maintenance services

2. The research was only conducted on consumers in Jakarta who use elevators as a transportation means vertical in their buildings. Therefore, further research can add the number of regions and respondents as the population and sample.

3. This research was conducted by taking samples of various brands of elevators and escalators. Therefore, further research can focus on one brand of elevator and escalator.

4. Companies must always pay attention to the safety stock of spare parts so that consumers can easily get them.

5. Companies must be quick to respond and be able to provide solutions to problems that occur in consumer lifts and escalators.

6. Companies must continue to maintain relationships with consumers through various available media. Companies must continue to improve equipment, materials and technology for the products they produce.

7. Companies must be able to guarantee or provide guarantees for products and work performed on consumer units.

8. Companies must continue to improve the ability of features in accordance with standards product to be able to compete with competitors and become an attraction for consumers.

9. Companies must improve the resilience of spare parts so they are not damaged quickly.

10. Companies must continue to innovate to create various types of interior lifts and escalators.

11. Companies must continue to improve safety and technology for the products issued. 
12. Companies must be able to meet consumer expectations and satisfaction.

13. Companies must be honest and open to all information to consumers.

14. Companies must be able to provide satisfaction and fulfill all consumer desires so that the company is recommended by consumers to their colleagues.

\section{BIBLIOGRAPHY}

Ahmad Fardian Firdau., Sugiyono Madelan., Ahmad Badawi Saluy., (2021). "Supplier/Partnership Selection System Analysis Based on Analytic Hierarchy Method Process in Oil and Gas Drilling Project (Case Study: PT. KMI)". International Journal of Innovative Science and Research Technology, Vol.6, Issue 3,page. 403 -411.

Aks, S. M. Y., \& Prasetyo, B. S. (2019). Pengaruh Kualitas Jasa Pelayanan Dan Citra Merek Perusahaan Terhadap Minat Konsumen Pada Penggunaan Jasa PT Quest Geophysical Asia. 1-13.

Amalia Utami Dewi., Madelan, Sugiyono., Ahmad Badawi saluy., (2021)" Analysis of the Application of Total Quality Management in Lens Products in PT. XYZ" Scholars Bulletin, Scholars Bulletin. Vol.7, Issu,3. Page, 14-20

Amron. (2018a). The Influence of Brand Image, Brand Trust, Product Quality, and Price on the Consumer's Buying Decision of MPV Cars. European Scientific Journal, ESJ, 14(13), 228. https://doi.org/10.19044/esj.2018.v14n13p228

Amron, A. (2018b). Effects of Product Quality, Price, and Brand Image on the Buying Decision of City Car Product. Archives of Business Research, 6(4), 1-8. https://doi.org/10.14738/abr.64.4374

Aptaguna, A., \& Pitaloka, E. (2016). Pengaruh Kualitas Layanan Dan Harga Terhadap Minat Beli Jasa Go-Jek. Widyakala Journal, 3(2012), 49. https://doi.org/10.36262/widyakala.v3i0.24

Ariani, D. W. (2014). Manajemen Operasional dan Strategi Operasional. In Lingkarlsm.Com. http://lingkarlsm.com/manajemen-operasional-dan-strategi-operasional/

Christie H. K. Pasaribu., Sugiyono Madelan., Saluy,Ahmad Badawi., (2021)" Single and Multifactor Productivity Analysis of Manual and Automatic Machines at Powder Coating Company PT. TKM in Bekasi” International Journal of Innovative Science and Research Technology, International Journal of Innovative Science and Research Technology, Vol.6, Issue, 2. Page, 518-524.

Dicky Darmajaya, I. B., \& Sukawati, T. G. R. (2018). Peran Citra Merek Memediasi Pengaruh Kualitas Produk Terhadap Keputusan Pembelian. E-Jurnal Manajemen Universitas Udayana, 7(12), 6931. https://doi.org/10.24843/ejmunud.2018.v07.i12.p01

Doddy Agustiandi., Sugiyono Madelan., Saluy,Ahmad Badawi.,(2021)." Quality Control Analysis Using Six Sigma Method to Reduce Post Pin Isolator Riject in Natural Drying Pt Xyz". International Journal of Innovative Science and Research Technology.Vol.6.Issu, 1.Page, 1417-1426.

Fahrian, F., Hasiolan, L. B., \& Haryono, A. T. (2015). Pengaruh Citra Merek, Lokasi, Kepercayaan Dan Kualitas Pelayanan Terhadap Minat Membeli Bbm Di Spbu Gasindo Mekar Putra Semarang. Journal of Management, $1(1), \quad 110$. http://jurnal.unpand.ac.id/index.php/MS/article/view/261

Fatihudin, D., Mochklas, M., \& Suryati, D. A. (2020). The Effect of Brand Image Perception and 
Product Quality Toward the Interest to Buy Consumer Pre-Pay IM3 Ooredoo. 436, 53-57. https://doi.org/10.2991/assehr.k.200529.011

Ghazali, D., Magister, P., Industri, T., Sarjana, P. P., \& Buana, U. M. (2018). Desain Peningkatan Kepuasan Pelanggan Dalam Industri Jasa Pemeliharaan Lift Dan Eskalator.

Heizer, J., \& Render, B. (n.d.). Operations Management -10th Edition 2011 - JayHeizer \& Barry Render.pdf.

Heizer, J., Render, B., \& Munson, C. (2017). Operations Management: Sustainability and Supply Chain Management. In Pearson Education.

Illah, M. M., \& Nugraha, S. A. (2020). Pengaruh Promosi , Harga dan Citra Merek Terhadap Minat Pemakaian Jasa Fotografi. 3, 120-133.

Levyda, L., Ramadhanty, N. N., \& ... (2015). Pengaruh Kualitas Pelayanan terhadap Citra Merek: Studi Kasus Pada Long-Stay Guest Oakwood Premier Cozmo Jakarta. Seminar Nasional \& ..., November 2015. http://repository.usahid.ac.id/563/1/18. Pengaruh Kualitas Pelayanan Terhadap Citra Merek.pdf

Lien, C. H., Wen, M. J., Huang, L. C., \& Wu, K. L. (2015). Online hotel booking: The effects of brand image, price, trust and value on purchase intentions. Asia Pacific Management Review, 20(4), 210-218. https://doi.org/10.1016/j.apmrv.2015.03.005

Liu, C., Bao, Z., \& Zheng, C. (2019). Exploring Consumers' Purchase Intention in Social Commerce : An Empirical Study Based on Trust, Argument Quality, and Social Presence. Asia Pacific Journal of Marketing and Logistics, 31(2), 378-397. https://doi.org/10.1108/APJML-05-2018-0170

Phung, M. T., Ly, P. T. M., \& Nguyen, T. T. (2019). The Effect of Authenticity Perceptions and Brand Equity on Brand Choice Intention. Journal of Business Research, 101(19), 726-736. https://doi.org/10.1016/j.jbusres.2019.01.002

Putri, L. G. D. anggara, \& Sukaatmadja, I. P. G. (2018). Peran Kepercayaan Memediasi Citra Merek Terhadap Niat Beli Pada Produk Smartphone Samsung Di Kota Denpasar. E-Jurnal $\begin{array}{llll}\text { Manajemen } \quad \text { Universitas } & \text { Udayana, }\end{array}$ https://doi.org/10.24843/ejmunud.2018.v07.i05.p06

Raditya, B., Yuliati, L. N., \& Krisnatuti, D. (2019). Analysis of the Effect of Brand Image, Product Quality and After-Sales Service on Repurchase Decision of Samsung Smartphones. Russian Journal of Agricultural and Socio-Economic Sciences, 92(8), 19-32. https://doi.org/10.18551/rjoas.2019-08.03

Ray, A., Kumar, P., Chakraborty, S., \& Dasgupta, S. A. (2020). Exploring The Impact of Different Factors on Brand Equity and Intention to Take up Online Courses From eLearning Platforms. Journal of Retailing and Consumer Services, October, 102351. https://doi.org/10.1016/j.jretconser.2020.102351

Rusdiana, H., Moh Ali Ramdhani, P. H., \& Guru Besar UIN Sunan Gunung Djati Bandung, M. (2014). Manajemen Operasi. http://digilib.uinsgd.ac.id/8788/1/Buku Manajemen Operasi.pdf

Saleem, M. A., Zahra, S., \& Yaseen, A. (2017). Impact of Service Quality and Trust on Repurchase Intentions - The Case of the Pakistan Airline Industry. Asia Pacific Journal of Marketing and Logistics, 29(5), 1136-1159. https://doi.org/10.1108/APJML-10-2016-0192

Saluy, A. B., \& Kemalasari, N. W. (2017, July). Analisis Pengaruh Kualitas Pelayanan, Kualitas 
Produk, Dan Harga Terhadap Keputusan Pembelian Pelanggan PT. XYZ. In Seminar Ekonomi dan Bisnis (SNEBIS) (Vol. 1, No. 1).

Santoso, A., \& Harmoni. (2016). Pengaruh Kualitas Produk Dan Ekuitas Merek Terhadap Keputusan Pembelian. Ekuilibrium: Jurnal Ilmiah Bidang Ilmu Ekonomi, 11(1), 43. https://doi.org/10.24269/ekuilibrium.v11i1.112

Shi, S., Mu, R., Lin, L., Chen, Y., Kou, G., \& Chen, X.-J. (2018). The Impact of Perceived Online Service Quality on Swift Guanxi : Implications for Customer Repurchase Intention. Internet Research, 28(2), 432-455. https://doi.org/10.1108/intr-12-2016-0389

Sinaga, D., Madelan, S., \& Saluy, A. B., (2021). Analysis Supply Chain Management Performance Using SCOR Method in Compressor Distributor Company at PT. Pola Petro Development. International Journal of Innovative Science and Research Technology, Volume 6, Issue 2, February - 2021,Page 91-102.

Slack, N., Brandon-Jones, A., \& Jhonston, Ro. (2013). Operations Management, Seventh Edition. In Pearson Education. https://doi.org/10.4135/9781446262733

Slack, N., \& Lewis, M. (2008). Operations strategy, Second Edition. In Pearson Education. https://doi.org/10.4324/9780203361528_chapter_11

Stevenson, W. J., \& Chuong, S. C. (2013). Manajemen Operasi Perspektif Asia. Analisis Pendapatan Dan Tingkat Kesejahteraan Rumah Tangga Petani, 53(9), 1689-1699.

Sugiyono. (2010). Metode Penelitian Bisnis (Pendekatan Kuantitatif, Kualitatif dan R\&D).

Sugiyono. (2020). Optimalisasi Ekspor Produk Ekonomi Kreatif Indonesia Menuju Peningkatan Dayasaing. Business Economic, Communication, and Social Sciences, 2(3), 33-44.

Susilana, R. (n.d.). Modul Populasi dan Sampel. http://file.upi.edu/Direktori/DUALMODES/PENELITIAN_PENDIDIKAN/BBM_6.pdf

Tong, X., \& Su, J. (2018). Exploring Young Consumers' Trust and Purchase Intention of Organic Cotton Apparel. Journal of Consumer Marketing, 35(5), 522-532. https://doi.org/10.1108/JCM-04-2017-2176 